\title{
Factors Affecting Bas' Performance (Cooking Coordinator) in Pangkep District
}

\author{
Lina Mariana ${ }^{1}$, Kustiyono ${ }^{2}$, Muhammad Dakhri Sanusi ${ }^{3}$, Hardi Utomo ${ }^{4}$, Sri Indira Hartawati ${ }^{5}$ \\ Politeknik Informatika Nasional Makassar ${ }^{1}$, Universitas Ngudi Waluyo ${ }^{2}$, Politeknik \\ Informatika Nasional Makassar ${ }^{3}$, STIE AMA Salatiga ${ }^{4}$, STIE Yapman Majene ${ }^{5}$
}

$\left\{\right.$ linamariana90@yahoo.co.id $\left.{ }^{1}\right\}$

\begin{abstract}
A bas' (cooking coordinator) is in charge of the food available at the event. This study aims to determine the factors that influence the performance of Bas' (cooking coordinator) in Pangkep district. The method of analysis used in this research is descriptive qualitative. After analyzing and discussing it, the authors conclude that there is an effect of motivation on bass performance (coordinator) in Pangkep district, 2) there is an influence of competence on bas performance (head cook).
\end{abstract}

Keywords: motivation; competence; bas'(cooking coordinator)

\section{Introduction}

Bas' (cooking coordinator) is the person in charge of food. One of the things that is the key to the success of holding a wedding ceremony for the Bugis-Makassar tribe in South Sulawesi is bas' (cooking coordinator). Bas' is very trusted by the host organizers to process the food that will be served to their guests. A bas 'is also a keeper of siri' (shame) of the host. He had to make sure the dishes didn't run out before the last guest arrived. He kept the honor of the host.

In ancient times Bas' usually came from the close family of the party organizers. However, nowadays $B a s^{\prime}$ already has a team consisting of men and women who do not come from the family that organizes the party, but from the general public. As it is known that food offerings in the Bugis tradition are not small. In the food code, the host who organizes the reception will entrust it to a jennang or also known as 'bas'. Usually, one person is appointed to be authorized for the entire serving, both in terms of quantity, type and time of serving. Anything that is served on the first day until the event ends is also the responsibility of the bas " (cooking coordinator).

The development of the times demands the community of the bas' not displaced and reduced. They must be able to maintain their existence by showing good performance. The existence of cathering services that is increasingly mushrooming of course can be a threat to bas' (cooking coordinator) especially those who make the bas 'profession the main income of the family. Of course, as a bas (cooking coordinator), he is required to have a good performance through his competence and also the need for motivation so that a bas ' 'has a good performance.

Currently, to see the performance of the basses, it can be seen from the success of a bassist in serving delicious and sufficient food. The person designated as bas' is a person who is 
considered an expert with a lot of experience. In one environment there is one person who is believed to be a bas' (cooking coordinator). Until the person in question is no longer able to carry out their duties, it is agreed that other parties who are considered capable of continuing. With a long experience, a bassist is able to have the competence as a good cooking coordinator or kitchen commander. With these competencies, it is hoped that a bassist will have a good performance.

\section{Theoretical basis}

In Bugis, especially at weddings, usually the event organizer entrusts several people to arrange so that each procession in the wedding can take place well. People who are entrusted with managing the food are usually referred to as jennang or better known as bas'. [1]

Bas' (cooking coordinator) is also known as the commander of the kitchen. Bas' or the cooking coordinator is in charge of determining the menu, supervising the cooking process, and distributing the work to the mothers who help out. Often the distribution of the work took into account their social status. [2] A bas 'in carrying out his duties and functions, of course, a good performance is required from the host or the event owner. But to have a good performance, a bas is certainly influenced by several factors, including competence and motivation.

Someone who is competent in their field will make it easier for that person to produce good performance. According to [3] that: "Competence is an ability to carry out or perform a job or task which is based on skills and knowledge and is supported by the work attitude demanded by the job. According to Michael Zwell ( Wibowo,2014) the factors that influence competence include: 1) beliefs and values, 2) skills, 3) experience, 4) personality characteristics, 5) motivation, 6) emotional issues, 7) intellectual abilities, and 8) organizational culture.

According to Michael Zwell According to Purwnono et al [4],motivation is an important thing besides competence that can encourage good performance. With high motivation will create a commitment to what is his responsibility in completing every job. Motivation is very necessary, every individual needs it as a driving force so that they can be more enthusiastic in carrying out their work. Motivation can take the form of financial or non-financial.

\section{Results and Discussion}

Pangkep Regency is $52.7 \mathrm{~km}$ from Makassar city. At a traditional Bugis wedding party in Pangkep district, party owners usually use the service "bass" to arrange the food menu that will be served during the party. Most of the Bugis tribes in Pangkep district still use the services of a bass'. This they do because they believe that bas' has the ability to regulate food.

\subsection{Effect of motivation on bas' (cooking coordinator) performance}

To find out the motivation of the bas so that they have performance, the researchers conducted interviews with several key informants. As stated by Mrs. Hj. Ruskiah that: I became a bas' because there are still many people who need bas services' (cooking coordinator) at every event, especially weddings. When it comes to performance, thank God all who use my services are satisfied with my performance. In this village, my services as 
a bas' are often used by the community. Especially at weddings. I have also traveled to Kalimantan, traveling around South Sulawesi, to Bali. From taking care of the simplest events in houses to buildings to the most guests with around 800 people. As long as I was a bas' (cooking coordinator) I always worked optimally, because I didn't want to disappoint the celebration owner. Because a bas is also responsible for guarding siri '(shame). We will be very embarrassed if the taste of food we provide is not good or runs out even though there are still many guests. Therefore, we as bas' also have to work well (carry out our duties and responsibilities) so that there are still those who want to use my services when there is an event. Especially now that many cathering services have started to mushroom in this village. (interview, 05 December 2020)

Meanwhile, Mrs. Faridah said: I have to give my best everytime I serve as pa'bas. My motivation is not only because I have to maintain siri '(shame) from the owner of the celebration, I am also motivated to maintain the Bugis tradition, especially the type of food that will be served at sacred events "(interview, 06 December 2020)

From the interview above, the researcher can conclude that motivation is very influential on performance. This was told by the informant, that his motivation to perform well was to guard the siri' (shame) of the party owner as well as to maintain the tradition. In addition, his motivation to perform well is that his profession will be increasingly recognized by the surrounding community, and the more people will use his services. If a bas' does not have a good performance, the community will no longer use her services.

\subsection{Effect of competence on bass performance (cooking coordinator)}

According to Mrs. Hj Ruskiah's said: Being a bas' is not easy. I learned to be a bass' (cooking coordinator) and various food menus since I was little. Since I was in 4th grade, until I was a teenager, I could slowly become a bas "in a wedding ceremony". Becoming a bas' is not easy, because you have to be good at managing both the amount of food, the type of food you will make, and regulating the amount of labor you will use. It's not easy to be bas' without experience. (interview, 05 December 2020)

Meanwhile, in a different place, Mrs. Faridah explained that: I learned to cook since graduating from vocational high school. I continue to improve my cooking skills. And I was bass' the first time after I got married. Being bass' is not an easy thing. We must have the ability, one of which is to master all types of typical Bugis cuisine, especially the special foods that will be served at weddings. (interview, 06 December 2020)

According to Mr. Darman: Ummi sukiah has long been a bas'. So the average person in this village (Pangkep district) already knows his abilities. We are also in the family when there is an event, we usually call Ummi Sukiah (Mrs. Hj Ruskiah) to be a bas'. Because apart from the delicious food, the amount of food is always served to the invited guests. (interview, 10 December 2020)

From the above interview, the writer draws the conclusion from the three informants above, that the competence they have as a bassist 'they get through a long experience. From this experience they finally became experts in their fields. The results of this study are in accordance with Michael Zwell's theory (Wibowo, 2014) that the factors that influence competence, one of which is experience. With the competencies they have, it is certain that their performance is good. This is evidenced by the results of interviews with Mr. Darman who often uses the services of Mrs. Hj Ruskiah as a bas. 


\section{Conclusions and suggestions}

\subsection{Conclusion}

After analyzing and discussing it, the authors conclude that

a. There is a motivational influence on the performance of bas' (cooking coordinator) in Pangkep district. Key informants found the same motivation so that they have to perform well.

b. There is an influence of competence on bas performance (cooking coordinator). Competence is obtained from a long experience. With the competencies of a bassist, he is able to perform well. The results of its performance can be felt by the people who use its services.

\subsection{Suggestion}

a. We recommend that users of bas services' give the wages appropriate. So that the offspring of the $b^{\prime} s^{\prime}$ can be motivated to be bass too. Because being a bas' (cooking coordinator) can not only create jobs, but also help the family economy.

b. We recommend that the local government participate in maintaining the 'pure bas (descendants of' original bas). Because this bas is also one of the cultures in Pangkep district which is almost extinct because it has been replaced by catering services.

\section{Acknowledgements}

The author would like to thank the local government for giving permission to the author to carry out data collection. The author would also like to thank to ICLSSEE 2021 for giving our article the opportunity to be published.

\section{References}

[1] porosmaju, ,Seorang Bas dan Keberhasilan Acara dalam Tradisi Pernikahan Bugis,“ 19 Februari 2018. [Online]. Available: https://porosmaju.com/seorang-bas-dankeberhasilan-acara-dalam-tradisi-pernikahan-bugis/.

[2] kompas.com, „Doa Sang Komandan Dapur,“ 24 Oktober 2013. [Online]. Available: https://properti.kompas.com/read/2013/10/24/1458513/NaN?page=all.

[3] Wibowo, Manajemen Kinerja, Edisi Kelima, Jakarta: Rajawali Pers, 2007.

[4] Yuliana, „Pengaruh Kompetensi dan Motivasi Kerja Terhadap Kinerja Karyawan Perusahaan pada PT Haluan Star Logistik,“Jurnal Ilmiah Manajemen Bisnis, zv. XVII, \%1. vyd.2, 2017.

[5] Wibowo, Manajemen Kinerja, Jakarta: PT Rajagrafindo Persada, 2014. 